ORİJINAL MAKALE / ORIGINAL ARTICLE

Balıkesir Sağlık Bilimleri Dergisi / BAUN Sağ Bil Derg

Balıkesir Health Sciences Journal / BAUN Health Sci J

ISSN: 2146-9601- e ISSN: 2147-2238

Doi: https://doi.org/10.53424/balikesirsbd.841092

\title{
The Effect of Non-Pharmacological Pain Management Training Given to Parents of Children with Sickle Cell Disease on Parents' Knowledge in Two Different Countries
}

\section{Fatima El Zahra AMIN FADIL ${ }^{1}$, Emine EFE 國}

\author{
${ }^{1}$ Ministere de la Sante Publique Sous-Direction de la Pharmacopee, Chad \\ ${ }^{2}$ Akdeniz University, Nursing Faculty, Child Health Nursing Department, Antalya, Turkey
}

This study was prepared as a master's thesis and was presented as a verbal declaration at the 6th National 1st International Pediatric Nursing Congress. Antalya, Turkey (15-19 November 2018).

Geliş Tarihi / Received: 15.12.2020, Kabul Tarihi / Accepted: 06.04.2021

\begin{abstract}
Objective: The aim of this study is to evaluate the effect of non-pharmacological pain management education program for parents of children with sickle cell disease living in two different countries on the knowledge level of parents. Methods: This study is a descriptive study. The study was conducted with a sample of 163 parents (109 Chadian and 54 Turkish). The researcher gave the training program to the parents. Participants' knowledge were examined at the baseline and three weeks after intervention. After the education, the knowledge levels of the parents were evaluated with a non-pharmacological methods questionnaire. Results: It has been determined that children with sickle cell disease in Chad have a crisis every 2-3 months. If the children in Turkey were found to experience pain crisis between 7 months to 1 year. Parents who have been trained for non-pharmacological methods have advanced knowledge about methods used to reduce pain in children with sickle cell disease. At the end of the training, it was determined that Turkish participants knew more about the statements "painting can reduce pain, taking a bath with hot or warm water can reduce pain, changing positions can reduce pain". At the end of the training program, participants in Chad were found to have more knowledge of the statements "painting can reduce pain, changing positions can reduce pain, and playing games and distractions can reduce pain". Conclusion: Non-pharmacological methods training program for parents of sickle cell disease children was found to be effective in increasing the knowledge level of parents in both countries.
\end{abstract}

Keywords: Chad, Child, Non-pharmacological method, Sickle cell disease, Turkey.

\section{Orak Hüicre Hastalığı Olan Çocukların Ebeveynlerine Verilen Nonfarmakolojilk Ağrı Yönetimi Eğitiminin İki Farklı Ülkedeki Ebeveynlerin Bilgisine Etkisi}

\section{ÖZ}

Amaç: Bu çalışmanın amacı, iki farklı ülkede yaşayan orak hücre hastalığı olan çocukların ebeveynleri için hazırlanan nonfarmakolojik ağrı yönetimi eğitim programının ebeveynlerin bilgi düzeyi üzerindeki etkisini değerlendirmektir. Gereç ve Yöntem: Çalışma tanımlayıcı niteliktedir. Çalışma 163 ebeveynin (109 Çadlı ve 54 Türk) örneklemiyle gerçekleştirilmiştir. Araştırmacı eğitim programını ebeveynlere uyguladı. Katılımcıların bilgisi başlangıçta ve müdahaleden üç hafta sonra incelendi. Eğitimden sonra ebeveynlerin bilgi düzeyleri nonfarmakolojik yöntemler anketi ile değerlendirildi. Bulgular: Çad'daki orak hücre hastalıklı çocukların 2-3 ayda bir kriz yaşadığı belirlendi. Türkiye'deki çocukların ise 7 ay ila 1 yıl arasında ağrı krizi yaşadığı saptandı. Nonfarmakolojik yöntemlere yönelik eğitim almış ebeveynler orak hücre hastalığı olan çocuklarda ağrıyı azaltmak için kullanılan yöntemlere yönelik ileri düzeyde bilgi sahibi olmuşlardır. Eğitimin sonunda, Türk katılımcıların "resim yapmak ağrı1 azaltabilir, sıcak veya 1lık suyla banyo yapmak ağrıyı azaltabilir, pozisyon değiştirmek ağrıyı azaltabilir" ifadelerini daha fazla bildikleri saptandı. Çad'daki katılımcıların eğitim programının sonunda "resim yapmak ağrıyı azaltabilir, pozisyon değiştirmek ağrıyı azaltabilir ve oyun oynamak, dikkat dağıtıcı şeyler ağrıyı azaltabilir" ifadelerine yönelik daha fazla bilgi sahibi olduğu saptandı. Sonuç: Orak hücre hastalığı olan çocukların ebeveynleri için nonfarmakolojik yöntemler eğitim programının her iki ülkedeki ebeveynlerin bilgi düzeyini artırmada etkili olduğu bulunmuştur.

Anahtar Kelimeler: Çad, Çocuk, Nonfarmakolojik yöntem, Orak hücre hastalığı, Türkiye.

Sorumlu Yazar / Corresponding Author: Emine EFE, Akdeniz University Nursing Faculty 07058, Campus, Antalya, Turkey E-mail: eefe@akdeniz.edu.tr

Bu makaleye attf yapmak için / Cite this article: Amin Fadil, F.E.Z. \& Efe, E. (2021). The effect of non-pharmacological pain management training given to parents of children with sickle cell disease on parents' knowledge in two different countries. Ballkesir Să̆llk Bilimleri Dergisi, 10(3):235-243. https://doi.org/10.53424/balikesirsbd.841092

CCopyright 2021 by the Balıkesir Sağlık Bilimleri Dergisi.

BAUN Să̆ Bil Derg 2021 OPEN ACCESS https://dergipark.org.tr/tr/pub/balikesirsbd

This work is licensed under a Creative Commons Attribution-NonCommercial 4.0 International License 


\section{INTRODUCTION}

Sickle cell disease (SCD) is a hereditary disease (Crosby et al., 2014). Approximately 5\% of the world's population carries trait genes for haemoglobin disorders, mainly, SCD and thalassaemia. Haemoglobin disorders are genetic blood diseases due to inheritance of mutant haemoglobin genes from both, generally healthy, parents. SCD is characterized by recurrent, acute severe pain episodes due to vaso-occlusive crisis (VOC) (Vijenthira et al., 2012). These pain episodes have been characterized as sickle cell crises or pain crises. It was description of sickle cell pain as typically being sudden onset in the low back, or one or more joints or extremities (Ballas et al., 2012). These crises are the primary reason for health care utilization and they often result in hospitalizations (Wong, 2013; Lattimer et al., 2010). Haywood et al. (2013) reported that 171 of 789 patients who were referred to emergency services due to pain were patients with SCA. Opioids have been the primary therapy used to treat both acute VOC and chronic pain in SCD. Concerns about long-term opioid therapy in recent years have led to the need to promote nonpharmacologic methods to treat chronic pain. Chronic opioid therapy only addresses the sensory/physical dimension of pain for persons with SCD, and does not address other dimensions of life affected by chronic pain including affective, behavioral, cognitive, cultural, or social dimensions. For these reasons, it is important that non-pharmacological methods be investigated and used as complements to pharmacological therapies to address and treat both acute and chronic pain for those with SCD (Williams \& Tanabe, 2016). Methods used in nonpharmacological methods affect emotional, cognitive, behavioral and sociocultural dimensions of pain (Dampier et al., 2014). In a study that explored the use and perceived benefits of non-pharmacological methods by persons with SCD , 91.6\% $(n=208)$ of patients reported using at least one type of alternative therapy for pain management, and $23 \%$ $(n=48)$ reported benefits related to pain control by one of these approaches (Thompson \& Eriator, 2014). This high usage of non-pharmacological methods by persons with SCD has been replicated in other studies and ranges from $50 \%$ (Majumdar et al., 2013) to $70 \%$ (Yoon \& Black, 2006). Four evidence-based literature reviews of nonpharmacological methods used by persons with SCD have been published (Hildenbrand et al., 2014; Edwards \& Edwards, 2010; Chen, Cole \& Kato, 2004). These reviews conclude that nonpharmacological methods are effective in managing psychological and social complications of SCD, such as decreasing feelings of anxiety and depression, enhancing coping skills, and improving quality of life. National Heart Lung and Blood Institute (NHLBI) (2014) conclude that there is a general lack of research in the area of non-pharmacological management of pain for persons with SCD.

Jenerette et al. (2014) found that patients with SCD were trying to treat their pain at home and they did not want to apply for emergency services due to past treatment experience. It is very important that children with SCD be supported in coping with pain. Educating children and parents with SCD on pain and how to cope with pain will be effective in reducing pain crisis. A review study identifies important positive effects of educational interventions on patient knowledge of sickle cell disease and depression (Asnani et al., 2016). In this case, it is important for the nurses to establish educational programs for children and their parents on the illness and how to cope with the symptoms. Increased knowledge among children and family members may contribute to improved home quality of care, and enhanced quality of life. The World Health Organization (2011) is encouraging and supporting research to improve the quality of life of SCD patients. In the literature, there is no study evaluating the effectiveness of education for non-pharmacological methods for parents of children with sickle cell disease on parents' knowledge. We, therefore, believe that this study will fill this gap in the literature. The researcher, who was a dissertation student, came to Turkey from Chad in Southern Africa for educational purposes. The researcher stated that she wanted to provide the Chadian mothers of children with SCD with training on pain reducing nonpharmacological approaches that they needed very much. Therefore, the study was implemented in two countries. The aim of this study is to evaluate the effect of nonpharmacological pain management education program applied to parents of children with SCD on parents' knowledge in both countries.

\section{MATERIAL AND METHOD}

\section{Study design and participants}

This is a descriptive study. The research was conducted between September 2015 and February 2016 at the Mother and Child Hospital in Chad and the Children's Services in Chad-China Friendship Hospital. It was conducted in Turkey between April 2016 and July 2016 in Akdeniz University Hospital, Pediatric Hematology Service and Polyclinic of Mersin University Health Research and Application Center Hospital. The sample of the study consisted of the parents of children between the ages of 2 and 18 who came to the Pediatric Hematology service and outpatient clinic and were followed up with a diagnosis of sickle cell anemia. All parents who met the inclusion criteria on the dates of the study were included in the study. The research was carried out with 54 parents from Turkey and a 109 from Chad. The number of samples was calculated with a margin of error of $5 \%$ and a $95 \%$ confidence interval.

Inclusion Criteria: Parents of children between the ages of 2 and 18 with an oncological diagnosis; Turkish is spoken by parents and in Chad, parents can speak either Arabic or French; that at least one member of the family knows how to either read or write; and parents agreeing to face-to-face interviewing.

Exclusion criteria: Parents wanting to quit research.

\section{Measures}

Participant characteristics: The information form contained questions on parents' and their children's demographic characteristics (age, parents participating in the survey, education, parental occupation, family status and structure, marital status, number of children, number of siblings diagnosed with SCD). The children 
characteristics included age, sex, the frequency of the child's pain crisis, child's duration of sickle cell anemia (month).

Non-pharmacological Approaches of Pain Relief Parental Information Questionnaire (NAPRPIQ): Parents' pre- and post-educational knowledge of nonpharmacological approaches to pain reduction in children with SCD was measured using a closed-ended questionnaire developed by the researchers based on literature (She knows/She does not know) (Demir, 2012; Delicou \& Maragkos, 2013; Monti \& Yang, 2005; Williams \& Tanabe, 2016; Wong, 2013). Pre-test and posttest questions consist of 17 questions in total, including topics in education. There is a question for each nonpharmacological method. A preliminary study was carried out to determine the appropriateness and comprehensibility of the content of the data collection forms after obtaining permissions from the institutions for the research implementation. A pre-application was made to five parents in the Mother and Child Hospital in Chad. Preapplication was made in five parents admitted to University Hospital Pediatric Hematology Outpatient Clinic in Turkey.

\section{Training on nonpharmacological methods}

The training program, which we had prepared in accordance with the literature, provided training to parents about nonpharmacologic methods. This program was a 1 day course that ran for a total of 30 minutes. Accordingly, it is necessary to provide education for parents to learn nonpharmacological methods.

In the first stage of the study, an "Parent education booklet for nonpharmacological methods" was created by the researcher accordance with the literatüre (Williams \& Tanabe, 2016; Demir, 2012; Monti, 2005) to be given to the parents during and after the education. The Booklet; the parent education booklet containing the nonpharmacological methods that can be used for children before, during and after pain crisis was prepared in three (3) languages. For Turkey, the booklet was prepared in Turkish, and for Chad it was prepared in Arabic and French (Figure 1). Contents of the Booklet; definition of sickle cell anemia; nonpharmacological methods for reducing pain (increasing fluid and nutrient intake, massage, restricting/restoring movement, changing positions, avoiding extreme hot and cold conditions, taking pictures, avoiding stress, hypnosis, meditation); nonpharmacological methods used in drawing attention to other activities (listening to music, reading a book or story, watching a favorite program or film on TV, playing games, praising and praying, talking and chatting) (Figure 2). Five experts in relevant fields evaluated the suitability of the parent education booklet. The booklet was then piloted to check the content, clarity of language, ease of use. The pilot test sample consisted of a total of 10 parents (5 from Turkish and 5 from Chad). Parents included in the pilot study were not included in the study. Modifications were made to the booklet following analysis of the data from the pilot study. The second stage was to inform the participating parents about the study itself, their right to withdraw, and the content and overall purpose of the training.

\section{Data collection}

This study was performed in three steps: Step 1 (pre-test session): Face to face interviews were conducted with children and their parents in a room reserved in the outpatient hematology oncology clinic. The information form, and knowledge of non-pharmacological methods questionnaire were administered before intervention. Data collection lasted 10 to 15 minutes. Step 2 (training session): The researcher (first researcher/author) used the booklet (questions-answers) to provide participants with 30-40 min interactive individual training and discussed the booklet topics page by page. Participants' questions were also answered during the training. After the training session, the researcher distributed the booklets to participants.

Step 3 (post-intervention testing session): The researcher recorded the next session date of the children. Children generally visited the clinic once every 3 weeks. Therefore, the post-testing session was held 3 weeks after the intervention session. The knowledge of nonpharmacological methods questionnaire was administered to the parents to assess the effectiveness of the training. The researcher answered their questions as well. This study was performed under the supervision of the second author who was a child health and disease nursing professor and the thesis advisor of the first author. The researcher gave the training program to the parents by using a face-to-face interview method. The training was given individually to the parents in the meeting room where the children were treated. The study was first carried out with parents in Chad. Once there, the sample was applied to parents is reached in Turkey. Because of Chad's citizens one of the researchers in this study, data were collected in Turkey and Chad. Data were collected in two countries because the researcher believed that his parents in Chad needed training in non-pharmacological methods. Data analysis

Frequency, percentage, mean and standard deviation values were used as descriptive statistics for the scores.

\section{Ethical considerations}

The study was approved by the institutional local ethics committee. A written permission was obtained from Akdeniz University Hospital, Mersin University Health Research and Application Center Hospital, Chad Maternal and Child Hospital, Chad-Chinese Friendship Hospital. All participants provided their written informed consent. The survey was completed anonymously, and the participants were assured that their responses would be kept confidential.

\section{RESULTS}

A total of 163 parents with children diagnosed with SCD participated in the research with 109 from Chad and 54 from Turkey. The socio-demographic characteristics of children and their parents diagnosed with sickle cell disease in Turkey and Chad are given in Tables 1. The average age of the Chadian mothers was found to be $30.53 \pm 8.40$ and the average age of Turkish mothers was found to be $40.52 \pm 5.03$. The mean age of fathers from Chad was $41.51 \pm 10.68$, while the average age of Turkish fathers was $45.50 \pm 5.75$. The mean age of Chadian children 
was $6.34 \pm 4.37$, while the mean age of Turkish children was found to be $13.62 \pm 4.44$. The mean child's duration of sickle cell anemia of Chadian children was $54.21 \pm 44.75$ months, while that of Turkish children was $147.61 \pm 53.88$ months. It was found that children with sickle cell disease in Chad had a pain crisis every 2-3 months. The pain crises of children living in Turkey were found to spend between 7 months to 1 year.

Table 1. Some characteristics of participants in Chad, and Turkey.

\begin{tabular}{|c|c|c|c|c|}
\hline \multirow[t]{2}{*}{ Demographic Characteristics } & \multicolumn{2}{|c|}{$\begin{array}{c}\text { Chad } \\
(n=109)\end{array}$} & \multicolumn{2}{|c|}{$\begin{array}{c}\text { Turkey } \\
(n=54)\end{array}$} \\
\hline & $\mathbf{n}$ & $\%$ & $\mathrm{n}$ & $\%$ \\
\hline Parents participating in the survey & & & & \\
\hline Mother & 84 & 77.1 & 35 & 64.8 \\
\hline Father & 20 & 18.3 & 2 & 3.7 \\
\hline Both & 5 & 4.6 & 17 & 31.5 \\
\hline \multicolumn{5}{|l|}{ Mother's educational level } \\
\hline Illiterate & 37 & 34.0 & 6 & 11.1 \\
\hline Primary education & 36 & 33.0 & 38 & 70.4 \\
\hline High school & 20 & 18.3 & 7 & 13.0 \\
\hline University & 16 & 14.7 & 3 & 5.6 \\
\hline \multicolumn{5}{|l|}{ Occupation of the mother } \\
\hline Housewife & 62 & 6.9 & 43 & 79.6 \\
\hline Government employee & 19 & 17.4 & 3 & 5.6 \\
\hline Employee & 0 & 0.00 & 5 & 9.3 \\
\hline Self-employment & 28 & 25.7 & 3 & 5.6 \\
\hline \multicolumn{5}{|l|}{ Father's educational level } \\
\hline Illiterate & 27 & 24.8 & 0 & 0.0 \\
\hline Primary education & 18 & 16.5 & 42 & 77.8 \\
\hline High school & 24 & 22.0 & 10 & 18.5 \\
\hline University & 40 & 36.7 & 2 & 3.7 \\
\hline \multicolumn{5}{|l|}{ Occupation of the father } \\
\hline Unemployed & 3 & 2.8 & 1 & 1.9 \\
\hline Government employee & 47 & 43.1 & 5 & 9.3 \\
\hline Employee & 1 & 0.9 & 22 & 40.7 \\
\hline Self-employed & 57 & 52.3 & 21 & 38.9 \\
\hline Retired & 1 & 0.9 & 5 & 9.3 \\
\hline \multicolumn{5}{|l|}{ Marital status } \\
\hline Parents live together & 91 & 83.5 & 49 & 90.7 \\
\hline Divided (separation, death) & 18 & 16.5 & 5 & 9.3 \\
\hline \multicolumn{5}{|l|}{ Number of children in family } \\
\hline 1 & 14 & 12.8 & 9 & 16.7 \\
\hline 2 & 17 & 15.6 & 22 & 40.7 \\
\hline 3 and $\uparrow$ & 79 & 71.5 & 23 & 42.6 \\
\hline \multicolumn{5}{|l|}{ Number of siblings diagnosed with SCD } \\
\hline None & 65 & 59.6 & 25 & 46.3 \\
\hline 1 & 19 & 17.4 & 19 & 35.2 \\
\hline 2 & 10 & 9.2 & 4 & 7.4 \\
\hline 3 & 10 & 9.2 & 3 & 5.6 \\
\hline 4 and $\uparrow$ & 5 & 4.6 & 3 & 5.6 \\
\hline \multicolumn{5}{|l|}{ Sex of the child } \\
\hline Girl & 51 & 46.8 & 33 & 61.1 \\
\hline Boy & 58 & 53.2 & 21 & 38.9 \\
\hline \multicolumn{5}{|l|}{ The frequency of the child's pain crisis } \\
\hline Less than a month & 21 & 19.3 & 6 & 11.1 \\
\hline $2-3$ month & 33 & 30.3 & 9 & 16.7 \\
\hline 4-6 month & 32 & 29.4 & 10 & 18.5 \\
\hline 7 month-a year & 23 & 21.1 & 18 & 33.3 \\
\hline More than 2 years & 0 & 0.0 & 6 & 11.1 \\
\hline Does not go through & 0 & 0.0 & 5 & 9.3 \\
\hline Mother's mean age & & $30.53 \pm 8.4$ & & $40.52 \pm 5.03$ \\
\hline Father's mean age & & $41.51 \pm 10.68$ & & $45.50 \pm 5.75$ \\
\hline Children's mean age & & $6.34 \pm 4.37$ & & $13.62 \pm 4.44$ \\
\hline Child's duration of sickle cell anemia (month) & & $54.21 \pm 44.75$ & & $147.61 \pm 53.88$ \\
\hline
\end{tabular}


Table 2 shows significant differences between pre and posttests in response to the statements of the participants in Turkey, "bathing with hot or warm water can reduce
Pain", "changing position can reduce pain", "making pictures can reduce pain", and $(\mathrm{p}=0.003 ; \mathrm{p}=0.039$; $\mathrm{p}=0.012$, respectively).

Table 2. Evaluation of parents' knowledge about nonpharmacological methods before and after the training in Turkey.

\begin{tabular}{|c|c|c|c|c|}
\hline \multirow[t]{2}{*}{ Item } & \multirow[t]{2}{*}{ Test } & Agree & Disagree & \multirow[t]{2}{*}{$\mathbf{p}$} \\
\hline & & n (\%) & n (\%) & \\
\hline \multirow{2}{*}{$\begin{array}{l}\text { The use of medical drugs and } \\
\text { nonpharmacological methods before pain } \\
\text { prevents pain }\end{array}$} & Pretest & $46(85.2)$ & $8(14.8)$ & \multirow{2}{*}{0.070} \\
\hline & Posttest & $52(96.3)$ & $2(3.7)$ & \\
\hline \multirow{2}{*}{ Fluid intake can reduce the frequency of pain } & Pretest & $54(100.0)$ & - & \multirow{2}{*}{ - } \\
\hline & Posttest & $54(100.0)$ & - & \\
\hline \multirow{2}{*}{$\begin{array}{l}\text { Bathing with hot or warm water can reduce } \\
\text { pain }\end{array}$} & Pretest & $39(72.2)$ & $15(27.8)$ & \multirow{2}{*}{0.003} \\
\hline & Posttest & $50(92.6)$ & $4(7.4)$ & \\
\hline \multirow{2}{*}{ Massage can reduce pain } & Pretest & $48(88.9)$ & $6(11.1)$ & \multirow{2}{*}{0.289} \\
\hline & Posttest & $52(96.3)$ & $2(3.7)$ & \\
\hline \multirow{2}{*}{$\begin{array}{l}\text { In the presence of pain can limit the movement } \\
\text { restriction and rest pain }\end{array}$} & Pretest & $50(92.6)$ & $4(7.4)$ & \multirow{2}{*}{0.250} \\
\hline & Posttest & $53(98.1)$ & $1(1.9)$ & \\
\hline \multirow{2}{*}{ Changing position can reduce pain } & Pretest & $42(77.8)$ & $12(22.2)$ & \multirow{2}{*}{0.039} \\
\hline & Posttest & $49(90.7)$ & $5(9.3)$ & \\
\hline \multirow{2}{*}{$\begin{array}{l}\text { Avoiding extreme cold or hot environment } \\
\text { reduces pain }\end{array}$} & Pretest & $50(92.6)$ & $4(7.4)$ & \multirow{2}{*}{0.625} \\
\hline & Posttest & $52(96.3)$ & $2(3.7)$ & \\
\hline \multirow{2}{*}{ Playing games, distractions reduce pain } & Pretest & $46(85.2)$ & $8(14.8)$ & \multirow{2}{*}{0.180} \\
\hline & Posttest & $51(94.3)$ & $3(5.6 \%)$ & \\
\hline \multirow{2}{*}{ Relieving stress and daydreaming reduces pain } & Pretest & $52(96.3)$ & $2(3.7)$ & \multirow{2}{*}{1.000} \\
\hline & Posttest & $53(98.1)$ & $1(1.9)$ & \\
\hline \multirow{2}{*}{ Listening to music reduces pain } & Pretest & $42(77.8)$ & $12(22.2)$ & \multirow{2}{*}{0.146} \\
\hline & Posttest & $46(88.9)$ & $6(11.1)$ & \\
\hline \multirow{2}{*}{ Watching TV and reading books relieves pain } & Pretest & $43(79.6)$ & $11(20.4)$ & \multirow{2}{*}{0.920} \\
\hline & Posttest & $50(92.6)$ & $4(7.4)$ & \\
\hline \multirow{2}{*}{ Making pictures can reduce pain } & Pretest & $37(68.5)$ & $17(31.5)$ & \multirow{2}{*}{0.012} \\
\hline & Posttest & $46(85.2)$ & $8(14.8)$ & \\
\hline \multirow{2}{*}{ Praying relieves pain } & Pretest & $47(77.0)$ & $7(23.0)$ & \multirow{2}{*}{0.180} \\
\hline & Posttest & $52(96.3)$ & $2(3.7)$ & \\
\hline \multirow{2}{*}{ Talking and chatting reduce pain } & Pretest & $52(96.3)$ & $2(3.7)$ & \multirow{2}{*}{ - } \\
\hline & Posttest & $54(100.0)$ & - & \\
\hline
\end{tabular}

Table 3 shows that the highest percentage change for participants in Chad is in the items "making pictures can reduce pain", "changing position can reduce pain", and "playing games and distractions reduce pain". 
Table 3. Evaluation of parents' knowledge about nonpharmacological methods before and after the training in Chad.

\begin{tabular}{|c|c|c|c|}
\hline \multirow[t]{2}{*}{ Item } & \multirow[t]{2}{*}{ Test } & Agree & Disagree \\
\hline & & n (\%) & n (\%) \\
\hline \multirow{2}{*}{$\begin{array}{l}\text { The use of medical drugs and nonpharmacological } \\
\text { methods before pain prevents pain }\end{array}$} & Pretest & $109(100.0)$ & - \\
\hline & Posttest & $109(100.0)$ & - \\
\hline \multirow[t]{2}{*}{ Fluid intake can reduce the frequency of pain } & Pretest & $104(95.4)$ & $5(4.6)$ \\
\hline & Posttest & $109(100.0)$ & - \\
\hline \multirow[t]{2}{*}{ Bathing with hot or warm water can reduce pain } & Pretest & $60(55.0)$ & $49(45.0)$ \\
\hline & Posttest & $109(100.0)$ & - \\
\hline \multirow[t]{2}{*}{ Massage can reduce pain } & Pretest & $85(78.0)$ & $24(22.0)$ \\
\hline & Posttest & $109(100.0)$ & - \\
\hline \multirow{2}{*}{$\begin{array}{l}\text { In the presence of pain can limit the movement } \\
\text { restriction and rest pain }\end{array}$} & Pretest & $59(54.1)$ & $50(45.9)$ \\
\hline & Posttest & $109(100.0)$ & - \\
\hline \multirow[t]{2}{*}{ Changing position can reduce pain } & Pretest & $13(11.9)$ & $96(88.1)$ \\
\hline & Posttest & $109(100.0)$ & - \\
\hline \multirow{2}{*}{$\begin{array}{l}\text { Avoiding extreme cold or hot environment reduces } \\
\text { pain }\end{array}$} & Pretest & $101(92.7)$ & $8(7.3)$ \\
\hline & Posttest & $109(100.0)$ & - \\
\hline \multirow[t]{2}{*}{ Playing games, distractions reduce pain } & Pretest & $35(32.1)$ & $74(67.9)$ \\
\hline & Posttest & $109(100.0)$ & - \\
\hline \multirow[t]{2}{*}{ Relieving stress and daydreaming reduces pain } & Pretest & $63(57.8)$ & $46(42.2)$ \\
\hline & Posttest & $109(100.0)$ & - \\
\hline \multirow[t]{2}{*}{ Listening to music reduces pain } & Pretest & $102(93.6)$ & $7(6.4)$ \\
\hline & Posttest & $109(100.0)$ & - \\
\hline \multirow[t]{2}{*}{ Watching TV and reading books relieves pain } & Pretest & $71(65.1)$ & $38(34.9)$ \\
\hline & Posttest & $109(100.0)$ & - \\
\hline \multirow[t]{2}{*}{ Making pictures can reduce pain } & Pretest & $3(2.8)$ & $106(97.2)$ \\
\hline & Posttest & $109(100.0)$ & - \\
\hline \multirow[t]{2}{*}{ Praying relieves pain } & Pretest & $58(53.2)$ & $51(46.8)$ \\
\hline & Posttest & $109(100.0)$ & - \\
\hline \multirow[t]{2}{*}{ Talking and chatting reduce pain } & Pretest & $85(78.0)$ & $24(22.0)$ \\
\hline & Posttest & $109(100.0)$ & - \\
\hline
\end{tabular}

\section{DISCUSSION}

The results showed that the training program was effective. The parents in Turkey group "bathing with hot or warm water can reduce pain", "changing position can reduce pain," "making pictures can reduce pain" substance was found to be significant differences in the information for. Before the training, $72.2 \%$ of the parents thought that hot or warm bath reduced the pain, this rate increased to $92.6 \%$ after the training.

It was observed that there was a positive change in the thoughts of the parents about these items. The booklet and training session can be used to improve Chadian and Turkish parents' ability to use nonpharmacological methods to reduce pain in their children with SCD. The booklet was tailored to the needs of children with SCD and their parents. During the 40-minute training session, the participants learned how to use the booklet and nonpharmacological methods that they can use in their children with SCD.

Zhu et al. (2018) reported that after the training program given to parents to equip their children with the knowledge and skills to manage post-operative pain, the knowledge of parents and nonpharmacological methods increased. In a study, as a result of the Interactive Therapeutic Game Training Program applied to children and mothers in preparation for surgery, it was observed that the State Anxiety Inventory and Beck Anxiety Scale scores of children who were trained in the postoperative period were lower than the control group (Coşkuntürk \& Gözen, 2018). He et al. (2011) examined the effect of an educational intervention (booklet distribution and lectures) on Singaporean nurses providing guidance to parents in the use of non-pharmacological pain relief 
for their children's postoperative pain. Study results suggested that the educational intervention had some impact on nurses' provision of guidance to parents on the use of non-pharmacological methods of pain relief for children's postoperative pain. In our study, it is seen that the knowledge of the majority of the parents about non-pharmacological methods after education increased as a percentage.

In the study, the knowledge of the participants about non-pharmacological methods after the training increased. After the training, they can continue to use the resources listed in the booklet to get updated information if they wish. The research showed that after the training, all Turkish participants had a positive change in their thoughts on the following statements. These statements; making pictures can reduce pain, bathing with hot or warm water can reduce pain, listening to music reduces pain, praying relieves pain. It can be said that the research caused positive changes in the opinions of all participants in Chad regarding the following statements after the training. These statements; making pictures can reduce pain, changing position can reduce pain, playing games, distractions reduce pain, praying relieves pain, in the presence of pain can limit the movement restriction and rest pain, bathing with hot or warm water can reduce pain, relieving stress and daydreaming reduces pain.

According to the results of the research, it can be said that the education given to parents in both countries causes positive changes in their attitudes towards nonpharmacological methods. The trained parents are thought to be able to reduce pain by applying nonpharmacological methods during pain attacks of children with SCD. Thrane (2013) reported in his review study that integrative interventions may be very effective for pain and anxiety in children undergoing cancer treatment. Madden et al. (2010) used creative arts therapy to evaluate changes in quality of life including pain and anxiety for children ages 2 to 21 years during chemotherapy treatment with a cancer diagnosis. In the study, it was reported that after creative art therapy, children's mood improved, they were more excited, happier and less angry. Post-White et al. (2009) found that all of the children felt better after the massage, physically, mentally, and emotionally. In the review study, 23 skills-training interventions reviewed, approximately half reported significant reductions in pain. A variety of skills-training interventions were included, including massage therapy, acupuncture, biofeedback, hypnosis, guided imagery, and aquatic rehabilitation (Asnani et al., 2016). Smith et al. (2018) reported that most parents used methods of giving a hot or warm bath and massaging. Dampier et al. (2002) reported that parents generally used the nonpharmacological methods of allowing the child to watch $\mathrm{TV}$, reading, talking, putting the child to sleep, giving the child a hot bath, massaging, praying and relaxation for home management of pain in SCD. Lemanek et al. (2009) investigated the effect of massage therapy on young patients with SCD and reported that those who received massage every day had less depression and anxiety and more functional status than those who did not. Although the study had a small sample size (n: 34), the results support that massage can be an effective way to help parents manage SCD pain and enhance relaxation and well-being. Increasing parents' knowledge of pain management can improve mood and other outcomes in young children in pain, helps parents learn behavioral strategies for both pain episodes and parenting challenges and reduces the development of dysfunctional coping patterns that make pain management difficult for both teens and parents (Barakat et al., 2007). Home pain management of children with SCD is critical. Parents play a key role in reducing the pain of children with SCD at home.

In the study, it was determined that the frequency of the child's pain crisis was 2-3 months in the Chad group and 7 months to 1 year in the Turkish group. This can also affect children's normal life processes, interrupting peer and family relationships. Jacob et al. (2006) in a study conducted in San Francisco among 27 children, aged 519 years, diagnosed with SCD, found that sickle cell anemia patients had an average of 2-3 times frequency of referral to the hospital a year due to a pain crisis. Therefore, such children should be provided with pain management at home. Parents can take an active role in pain management in the home environment, especially for children under the age of twelve.

This study has two limitations. The limitation is that the effect of non-pharmacological approaches used by participants on pain reduction was not measured. Future studies should evaluate the effectiveness of home management strategies employed by parents to relieve their children's SCD-related pain.

\section{Acknowledgment}

We would like to express our thanks to the parents who participated in this study. We are grateful to Professor Mehmet Ziya Firat for data analyses.

\section{Conflict of Interest}

The authors declare no potential conflicts of interest with respect to the research, authorship and/or publication of this article.

\section{Author Contributions}

Plan, design: FAF, EE; Materials and Methods: FAF, $\mathrm{EE}$; Data analysis and interpretation: FAF, EE; Writing and corrections: FAF, EE.

\section{Funding}

There are not significant competing financial, professional, or personal interests that might have influenced the performance or presentation of the work described in this manuscript.

\section{REFERENCES}


Asnani, M.R., Quimby, K.R., Bennett, N.R., Francis, D.K. (2016). Interventions for patients and caregivers to improve knowledge of sickle cell disease and recognition of its related complications. Cochrane Database of Systematic Reviews, 10(10), CD011175.

Ballas, S.K., Gupta, K., Adams-Graves, P. (2012). Sickle cell pain: a critical reappraisal. Blood, 120 (18), 3647-56.

Barakat, L.P., Patterson, C.A., Tarazi, R.A., Ely, E.B. (2007) Disease-related parenting stress in two sickle cell disease caregiver samples: Preschool and adolescent. Families Systems \& Health, 25(2), 147-161.

Chen, E., Cole, S.W., Kato, P.M. (2004). A review of empirically supported psychosocial interventions for pain and adherence outcomes in sickle cell disease. Journal of Pediatric Psychology, 29, 197-209.

Crosby, L.E., Simmons, K., Kaiser, P., Davis, B., Boyd, P., Eichhorn, T., Mahaney, T., Joffe, N., Morgan, D., Schibler, K., Anderson, V., Quinn, C.T., Kalinyak, K.A. (2014). Using quality improvement methods to implement an individualized home pain management plan for children with sickle cell disease. Journal of Clinical Outcomes Management, 21 (5), 210-217.

Dampier, C., Ely, B., Brodecki, D., Coleman, C., Aertker, L., Sendecki, J.A., Leiby, B., Kesler, K., Hyslop, T., Stuart, M. (2014). Pain characteristics and age-related pain trajectories in infants and young children with sickle cell disease. Pediatr Blood Cancer, 61, 291296

Dampier, C., Ely, E., Brodecki, D., O’Neal, P. (2002). Home management of pain in sickle cell disease: A daily diary in children and adolescents. Journal of Pediatric Hematology Oncology, 24(8), 643-647.

Demir, Y. (2012). Non-pharmacoogical terapies in pain management. In: Racz G, editors. Pain management current issues and opinions. World's largest Science, Technology \& Medicine Open Access book. 2012. p. 485-502.

Edwards, L.Y., Edwards, C.L. (2010). Psychosocial treatments in pain management of sickle cell disease. Journal of the National Medical Association, 102, 1084-1094.

Coşkuntürk, A.E., Gözen, D. (2018). The effect of interactive therapeutic play education program on anxiety levels of children undergoing cardiac surgery and their mothers. Journal of PeriAnesthesia Nursing, 33 (6), 781-789.

Haywood, C., Tanabe, P., Naik Beach, M.C., Lanzkron, S. (2013). The impact of race and disease on sickle cell patient wait times in the emergency department. The American Journal of Emergency Medicine, 31(4), 651656.

He, H.G., Jahja, R., Sinnappan, R., Ang, E.N., Lee, T.L., Chan, M.F., Vehviläinen-Julkunen, K. (2011). Singaporean nurses' provision of guidance to parents on nonpharmacological postoperative pain-relief methods: An educational intervention study. Nursing Health Sciecens, 13(3), 344-51.

Hildenbrand, A.K., Nicholls, E.G., Daly, B.P., Marsac, M.L., Tarazi, R., Deepti, R. (2014). Psychosocial and pharmacological management of pain in pediatric sickle cell disease. Postgraduate Medicine, 126(2) 123-133.

Jacob, E., Miaskowski, C., Savedra, M., Beyer, J.E., Treadwell, M., Styles, L. (2006). Changes in sleep, food intake, and activity levels during acute painful episodes in children with sickle cell disease. Journal of Pediatric Nursing, 21(1), 24-27.

Jenerette, C.M., Brewer, C.A.B., Edwards, L.J., Mishel, M.H., Gil, K.M. (2014). An intervention to decrease stigma in young adults with sickle cell disease. Western Journal of Nursing Research, 36(5), 599-619.

Lattimer, L., Haywood, C., Lanzkron, S., Ratanawongsa, N., Bediako, S., Beach, M. (2010). Problematic hospital experiences among adult patients with sickle cell disease. Journal of Health Care for the Poor and Underserved, 21(4), 1114-1123.

Lemanek, K.L., Ranalli, M., Lukens, C. (2009). A randomized controlled trial of massage therapy in children with sickle cell disease. Journal of Pediatric Psychology, 34(10), 1091-1096.

Madden, J.R., Mowry, P., Gao, D., Cullen, P.M., Foreman, N.K. (2010). Creative arts therapy improves quality of life for pediatric brain tumor patients receiving outpatient chemotherapy. Journal of Pediatric Oncology Nursing, 27(3), 133-45.

Majumdar, S., Thompson, W., Ahmad, N., Gordon, C., Addison, C. (2013). The use and effectiveness of complementary and alternative medicine for pain in sickle cell anemia. Complementary Therapy Clinical Practice, 19, 184-187.

Monti, D.A., Yang, J. (2005). Complementary medicine in chronic cancer care. Seminars in Oncology, 32(2), 225-231.

National Heart Lung Blood Institute (NHLBI) (2014). Expert panel report on the management of sickle cell disease (draft). 1-251.

Post-White, J., Fitzgerald, M., Savik, K., Hooke, M.C., Hannahan, A.B., Sencer, S.F. (2009). Massage therapy for children with cancer. Journal of Pediatric Oncology Nursing, 26(1), 16-28.

Smith, K., Reinman, L., Jeffrey Schatz, J., Roberts, C.W. (2018). Parent perspectives on pain management in preschool-age children with sickle cell disease. Journal of Pediatric Oncology Nursing, 35(1), 1624.

Thompson, W.E., Eriator, I. (2014). Pain control in sickle cell disease patients: use of complementary and alternative medicine. Pain Medicine, 15: 241-246.

Thrane, S. (2013). Effectiveness of integrative modalities for pain and anxiety in children and adolescents with cancer: A systematic review. Journal of Pediatric Oncology Nursing, 30, 320-332.

Vijenthira, A., Stinson, J., Friedman, J., Palozzi, L., Taddio, A., Scolnik, D., Victor, C., Campbell, F. (2012). Benchmarking pain outcomes for children with sickle cell disease hospitalized in a tertiary referral pediatric hospital. Pain Research and Management, 17(4), 291-296.

Williams, H., Tanabe, P. (2016). Sickle Cell Disease: A review of non-pharmacological approaches for pain. Journal of Pain Symptom Management, 51(2), 163-177.

Wong, D.L. (2013). Wong's nursing care of infants and children. (9th ed.). Canada; p. 1420-1433.

World Health Organization (2011). Sickle-cell disease and other haemoglobin disorders. http://www.who.int/mediacentre/factsheets/fs308/en/A ccessed 08.08.2017.

Yoon, S.L., Black, S. (2006). Comprehensive, integrative management of pain for patients with sickle-cell disease. Journal of Alternative Complementary Medicine, 12, 995-1001.

Zhu, L., Chan, W.S, Liam, J.L.W., Xiao, C., Lim, E.C.C., Luo, N., Cheng, K.F.K., He, H.G.J. (2018). Effects of postoperative pain management educational interventions on the 
outcomes of parents and their children who underwent an inpatient elective surgery: A randomized controlled trial. Journal of Advanced Nursing, 74(7), 1517-1530. 